\title{
Franklin Enterprises: The New Division
}

\author{
Crystal Ellis, Morgan State University, USA
}

Nathan Austin, Morgan State University, USA

\begin{abstract}
Franklin Enterprises, a leading supplier of industry plumbing, heating and cooling equipment, decided to set up an eBusiness division, Franklin Online (FOL), to develop online services for corporate account holders. Cody Lewis, an exemplary inside sales person, was appointed a Regional Business Development Manager (RBDM) for the newly established eBusiness division. With his sales skills, he created a team of sales people in his region that helped increase sales significantly through much quicker market penetration activities. He also worked closely with the other RBDM's in order to maximize the success of each territory. The very significant growth of the eBusiness division for corporate accounts led Franklin Enterprises to subsequently extend the service to the non-account consumer market as well.
\end{abstract}

Keywords: Organizational Development; Leadership; Strategy; Total Quality Management

\section{INTRODUCTION}

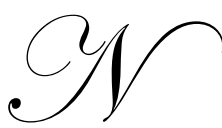

ot long after Cody Lewis was appointed a Regional Business Development Manager (RBDM) for the newly established eBusiness division, Franklin Online (FOL) of Franklin Enterprises, he had to make a presentation on the progress being made in his territory, to a group of branch, district, regional, and general managers. Most people would have probably been nervous doing that, but he saw it as a great opportunity to show how good he was in his position. As Cody was presenting, he noticed one of the branch managers from Philadelphia hand something to his boss, Brian Crichton, General Manager for eBusiness. Cody did not think anything of it then, but soon after his presentation, Brian came up and showed him a post-it note that said, 'Cody is awesome, the last guy sucked'. With a smile on Brian's face, his boss begun to address the crowd saying,

...the business development position was first held by George Lucas. It was a brand new position at the time and in its third year now. The position was then eBusiness sales and was more based around going across the country to teach branches how to use the website. The position has grown to become a more management type position where each Business Development Manager (BDM) is tasked with not only selling the website and other eBusiness capabilities to the customers, but also managing and creating a self-sufficient branch in all of their profit centers. Cody has been able to increase sales through his profit centers by incredibly managing not only the sales side with the customers, but also managing his profit center associates to be self sufficient...

\section{CASE}

\section{Cody Lewis}

Cody Lewis, a graduate of Northeastern University, has been the RBDM of the North East sector for FOL for a year. He joined the company about seven years ago right out of college and is making significant changes in his recently developed division. He has a heart for sales, which is why he was able to be so successful, even in his time away from FOL.

\section{The Company}

Franklin Enterprises, a Donavan-owned company, began operations in 1953, doubling in size every five years, for the first five decades. It deals in residential kitchen and bath supplies, commercial industrial supply, HVAC, and waterworks. Specifically, the company distributes the following: 


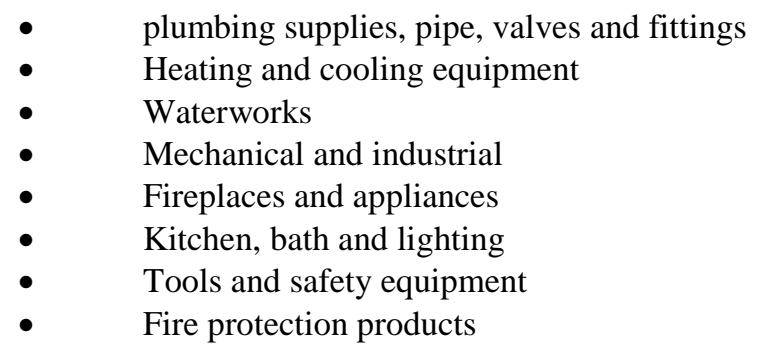

In 1982, Donavan acquired Franklin Enterprises and invested in growing the company. Franklin is the largest plumbing wholesaler in the nation. The company went from two locations back in 1953, to almost fifteen hundred today. Franklin Enterprises is located in all 50 states throughout the nation, with over 16,000 employees; and its mission statement includes the following:

- To be the premier customer-oriented supplier of value-added services.

- To continually improve our performance.

- $\quad$ To partner with vendors that help us meet our customers' needs.

- $\quad$ To provide our associates with a work environment that promotes communication and opportunities for personal growth and career development.

- To make a contribution to our communities, as individuals and as a company.

- $\quad$ To succeed as a business and to provide a return to our shareholders.

- $\quad$ To operate with integrity and achieve our mission in an ethical manner.

\section{Sales Force Training and Structure}

Franklin Enterprises believed that in order to build a solid foundation, each employee must understand every aspect of the company, including but not limited to processing orders, deliveries, product knowledge, etc. They were in constant search for the brightest college graduates, conducting recruiting programs that aggressively pursue students from across the country; but within each branch, management also hired at the local level to help ensure that they were meeting the local customers' needs. Newly hired employees went through a rigorous six-week training program designed to help ensure that they understood the importance of 'getting things right the first time'. During this training program, each employee worked at a main branch, learned about the company's culture, product coding, and the trilogy system that was used for creating orders. In addition to a 3-day culture and values training seminar at the corporate headquarters, a typical new employee training program covered shelves stocking tasks, managing orders, checking inventory, front counter order taking, and finally ending with inside sales responsibilities.

Once new employees completed the training program, they either remained at the main office to conduct inside sales or they got posted to a branch within the area. At the branch level, there was anywhere from one to about six inside sales personnel. While each branch may have been slightly different in the way they operated, they generally consisted of the following core personnel:

- Warehouse employees: stocking, inventory checks, order retrieval

- $\quad$ Front-Counter employees: take orders from customers that will come into the store

- $\quad$ Inside Sales employees: take orders from particular client bases, as well as call-in orders

- $\quad$ Outside Sales employees: go to the clients place of business everyday in order to generate orders

- Operations/Store Managers: oversee the employees, as well as helping in each division if necessary, and create reports for the main office to review

- $\quad$ Showroom employees: This is the consumer division of the company. They have a completely separate room, where they display all of their consumer goods. It allows for in-store residential design and purchases. 
The outside sales employees worked closely with inside sales employees. Once an outside sales person obtained an order, it was reported back to the inside sales personnel in order for it to be entered into the system. While there were options available to each inside sales person for promotion, the most common next step up the ranks was an outside sales position. The outside sales person was the only employee paid a commission-based salary, which made the position very attractive to employees. However, with the creation of the online division, many more opportunities opened up for employees.

\section{The eBusiness Division: Franklin Online}

Five years ago, the company decided to set up an eBusiness division, Franklin Online, to provide customers with established accounts, online access for checking their invoices and inventory, and place or check order status. It also allowed Franklin Enterprises and its customers to keep pace with the use of relevant order processing technological advances in the industry. As Franklin Enterprises saw tremendous value in its ability to provide the necessary tools to enable its customers to access its products, the initial critical goal was to educate both the customers and staff at the branches in the effective and efficient use of the site. They also needed customers using the site in order to provide feedback for improvements.

FOL was first made available to customers in Nashville, Tennessee, and Hampton Roads, Virginia. This brought in approximately $\$ 100,000$ dollars in sales. A year later, the company decided to expand the eBusiness through a pilot release to 100 customers in the metropolitan area of Northern Virginia, Maryland, and DC, which increased sales to approximately $\$ 300,000$ dollars. After that year, the very first branch rollout took place in Southern California for 3,000 customers. This allowed FOL's sales to increase to $\$ 10$ million dollars. The very next year, the company did a nationwide rollout, which increased membership to 22,000 customers, with approximately $\$ 58$ million dollars in sales. With the national rollout came the need for regional business development manager (RBDM) positions throughout the nation in order to help keep the focus on the customer.

\section{Competition}

Competition for FOL can be categorized on three critical factors; i.e., website sophistication and effectiveness, product variety and availability, and inventory management systems (Exhibit 1).

There was competition at both the national and regional levels in regard to website sophistication and effectiveness. Gavin was the competitor at the national level, though not a direct competitor in terms of the products it supplied. They focused on many more aspects other than plumbing and they did not have the specialization in plumbing that Franklin possessed. However, Gavin's website was more advanced and FOL had plans to be at par with Gavin, in that respect, in the next couple of years. Forestville and District Supply were the main direct product competitors at the regional level. The two had websites also, but not as efficient and effective as FOL's. For example, neither website offered search boxes, so the customer had to click through the huge amount of product categories just to get to the part that they were looking for. The main issue for these two companies was that they did not have the money to invest in the development of more sophisticated websites. On the other hand, FOL was able to invest $\$ 10$ million dollars in the development of its website and they reaped the benefits.

Franklin Enterprises was the only nationwide supply house, thus allowing them to have a wide range of stock readily available for its customers on a continuous basis. They had five distribution centers across the nation, each bigger than eight football fields put together, full of tons of ready-to-ship product items. They simply did not have any direct competition in regards to the scale of its company.

With regard to inventory management, its competitive bar-coding system enhanced the ability of its customers that had warehouses, to keep inventory on hand. These customers, with the help of Franklin Enterprises supply houses, were able to put a barcode on each product, which allowed for a much easier order processing in stock replenishment. Here again, there were no nationwide competitors but at the regional level. There were two main competitors within the northeast region - Essential Wholesalers and Buckley Supply. However, these two competitors did not have the technological advances or the inventory to support the orders that came in; a significant competitive opportunity for FOL. 


\section{Departure and Return}

When first employed, Cody Lewis, like all other new employees, went through several months of training at the main office before joining the inside sales force. He got down to work and immediately started posting relatively high sales numbers on a consistent basis. However, after $3^{1} \frac{1}{2}$ years of being with Franklin Enterprises and not receiving the promotion he desired, he started to wonder what else was out there. He ended up leaving Franklin and going to an outside sales position with a different company. During his exit interview with Franklin, his boss told him that he was always welcome back, an offer he later took advantage of to return to Franklin.

Cody recalls events leading to his departure and subsequent return to Franklin Enterprises saying, ...like everybody else, in three years you get that itch to leave and see what else is out there. I wanted to do outside sales, so I went and did it. At his new employer upon leaving Franklin Enterprises, Cody worked as an outside sales person for eight months, breaking sales records the first month he was there. However, he started to realize that Franklin could provide the best career opportunity for him. In his own words, I got over there and I saw that this job sucks. I went in there with full force and I tried, but the doctors and the lawyers that I had to deal with... So he contacted his former boss, thinking ...get me back to the plumbers, the construction workers, the real people that build the world. Plus, the people that work at Franklin are cool. With Franklin, it was during that time where everyone was letting people go because of the economy. So, as people were walking out the door, I was walking back in. So Cody went back to Franklin Enterprises within a week of making the request to return. He went back as an inside sales person for about a year and a half before the RBDM position became available.

\section{The Promotion}

Cody's boss at the time, Brian Bakowski, emailed Cody as soon as he heard about the opening that needed to be filled in the eBusiness division. Brian thought it would be perfect for Cody and asked him if he was interested. Cody took that information to his trainer, John Fosko, and asked that he talk to Brian about getting him in that position. John even discussed with the Sales Manager of eBusiness, Brian Crichton, about how well he thought Cody would do in the position. However, Mr. Crichton still felt it was necessary to give other people the opportunity to interview for the position. Cody was eventually given the appointment after four other applicants were interviewed. When Cody started in the new position, he was only provided information on the structure of eBusiness division and his responsibilities, but no specific instructions beyond that were provided.

Cody became the RBDM for the North Eastern sector, together with five other people throughout the country that also held an RBDM position for the North Central, North West, South East, South West, and Mid Atlantic sectors, respectively. Within his territory, Cody was responsible for creating new online corporate customers, whether they were new to Franklin and needed to establish an account, or they already had an established account and wanted more flexibility in ordering. Senior to the regional managers were functional managers, such as the Implementation Manager and the Service Manager, all of whom reported directly to the eBusiness Sales Manager. The Vice President of eBusiness oversaw the work of the Sales Manager as well as two other sector managers; i.e., the operations management and the search engine optimization/analytics managers. Under each sector RBDM operated a number of sales personnel (Exhibit 2).

The primary role of each RBDM was to sign up new corporate clients to the online services. It was their responsibility to go on sales calls with each branch outside sales person in order to promote the new eBusiness. Cody states,...I like the guys with inventory first because of bar coding - quickest win for us, quickest win for them. It doesn't lock them in because they can still go and buy it somewhere else, but if you can go out with your wireless scanner, scan your bar codes, plug it into your computer, and there's your order, who are you going to buy it from. The guy who you have to write it down for, type it into an email, and then wait on it to come back or just done. That is why I like those guys.... Yeah, I want to see the people with inventory first, but show me anybody you got because everybody can use it on some level, even if it is just finding their invoice on their own or seeing how much a 2" ball valve costs on a Saturday, suggesting that while he welcomed all customers, he particularly liked customers that held their own inventory. 


\section{Cody at Work}

Once a corporate account was created, a sales person responsible for that territory went into the customer's warehouse to bar code every single item and provided them with a wireless scanner where at any point they were able to scan any barcode. As and when required, the scanner would be plugged into their warehouse computer system to instantly update the inventory situation and also indicate the new orders required to replenish the inventory. The transactions were that quick. Cody dealt directly with outside sales people because they were paid a commission on top of their base salary for every order that was placed through their branch. Once an account was created, the orders remained linked to that particular branch where the credit account was initially created. Cody indirectly benefited financially from this arrangement. He received a sales report for his entire territory, which was linked to the bonus that he received each year.

Cody started to visit the outside sales people throughout his sector in order to establish a working relationship as well as initiate immediate contact with potentially new corporate customers. In a typical day on such visits, Cody would ride with an outside sales person who had up to four or five sales calls to make. He would let the customers know what the website was all about, discuss inventory issues, and based on the needs of the customer, provide several options about how the website could benefit them. It was not just about seeing customers that had never heard about FOL, but also to meet with customers, who didn't earlier want the service, to show them how much the website has made significant positive contribution to their operations since then. Besides these visits, he provided training at the actual branches for FOL employees in order to make sure that everyone really understood what the eBusiness Division had to offer.

During such in-house presentations, Cody would also identify how Franklin is a company that solves problems. For instance, one particular customer had an issue with inventory control of the supplies (i.e., gloves, tape measure, etc.) that they provided for their employees. The client did not want to charge its employees, but they did want a better system to help ensure that employees would only take what they needed. Cody described how the problem was resolved, saying...so we got this vending machine where it has this little LCD screen. They walk in and the guys get an authorization code, they punch it in, and just like how you buy a coke or a snickers bar, you select large gloves, and it drops. They take their stuff and they leave. This significantly reduced the company's inventory control issues because management was able to know which employees were taking the items and how many. Since the customer was about to deploy the machines at its job sites, Cody thought that once we get six of them instead of one, then I will go to the larger companies and say, "hey check this out." I use it more for when I present to say your guy might not be big enough for a vending machine, but this is something to say if they have a problem, we will figure it out. Think of it like we found a solution that fit.

The level of client responsiveness Cody demonstrated began to receive positive feedback. Every other week he held a conference meeting with all of the sector regional sales managers, the eBusiness sales manager, and the vice president to discuss sales. Based on what was going on in his territory and the rest of the nation, he realized the potential that was out there for furthering the business, but he felt that he needed more manpower. He went to his boss and informed him that he wanted to create his own sales team in order to more quickly meet the needs of the customers. He ended up creating three divisions - a plumbing profit center, a water works profit center, and a HVAC profit center - under him in the North East sector. Using the level of sales as the basis, he organized certain divisions by territory (Exhibit 3). Cody recalls how the sales effort was structured before he became a RBDM. ...before I got there, there were no teams, I have set all that up. I created it in order to ramp up the sales and the use of the website. They don't have a 'sales model', or a 'here's what you do model'... it is more of 'this is your territory, I hired you because you are the best, now go out there and do it'. I am creating the whole thing. Now, the other managers across the nation are trying to create and get their teams organized. After establishing his team, Cody set up weekly meetings where they went over sales, issues, and planning. Since he could only be in one spot at one time, his team did exactly what he did, but on a much smaller scale. Each team member had an established territory and a particular branch location that they worked out of (Exhibit 4). Each member of the team reported to Cody. In addition to holding conference calls, he also went out to each area to see how they were doing. Cody recalls his efforts during his visits by saying ...I get the stories going amongst everybody, so that Rochester knows that Boston is doing this and now Rochester will start doing it too. I created these teams so that Boston can help his outside sales person and customer. He can handle just about everything, but if he can't handle something, he just calls me and we can figure it out. So it is a lot better than having a 1,000 people calling me. 
Though Cody managed the team, the individual branches that they were associated with paid the members of the team. How well Cody did his job was reflected in the positive feedback received. In addition, he had access to performance data available via the eBusiness platform. For instance, regional managers, as well as their supervisors, could log on to the website to view the 'Dashboard' webpage. 'Dashboard' offered a quick glance as to how the eBusiness is doing on many different levels. It showed the month-to-date progress toward the monthly sales goals, comparison of processed previous and current month invoices, most recent daily activity and individual customer activity information. It also had drop-down boxes to enable access to current invoices by customer by branch as well as the branch account totals. This, not only allowed Cody to review his progress, but that of his team as well, by branch. Cody described what else he used the 'Dashboard' for, saying ... with it I can see first time buyers as well. I turn that into an email. Say that this location had three first time buyers, I will find out who the salesman is and who the inside guy is and copy the guy under me, calling him the Franklin champion of the month. It is all about pumping them up. While my goal is to have my team beat the rest of the nation, I still want Franklin, as a whole, to do well. So, if I find something that we are doing well, I will share with the rest of the RDM's.

During Cody's bi-weekly meetings with the other regional managers, he shared stories of what his team had done particularly well and how they did it. He saw these meetings as an opportunity to educate the other sales force of things that he had learned, as well as learning from the success stories of the other regional managers. Cody points out that "...each person in the group can do different things better. For example, one knows how to write all these programs that I have no idea how to do. So, I will call her to get her help. We work as a team; everybody has their strengths".

After Cody assumed RBDM position, sales via the eBusiness platform increased by $25 \%$ and the amount of customers has grown by more than $35 \%$. This year the company has increased their customer base to 30,000 people and increased their sales to $\$ 73$ million dollars.

The decision to invest in bar coding the inventory and subsequent purchases of account holders and the subsequent creation of the eBusiness platform brought significant benefits. First, the need for person-to-person sales calls was minimized as customers went online to place their orders. Second, the order process itself became a lot easier and convenient, while increasing the probability that customers who already logged in at the Enterprise Online webpage would either make additional required purchases to save having to get online again at a later period. Cody illustrates this observed client behavior referring to a Philadelphia-based client who was observed making entirely new product purchases after the bar coding exercise was complete. He said that “...the guy isn't going to be online and say ok I need 10 copper 90's, oh I'm online, I'm going to get 12; this is so much fun! He is going to buy the exact same thing he is going to buy regardless, but I am now taking it from the next guy because it is easier. Even if you know Franklin might be a little more expensive on an item, you are sitting there in front of your computer ...click, ordered, click, ordered...oh, I normally get that from someone else. Do I want to sit there and pick up the phone and call them having to re-enter it somewhere else, or do I just want to click again because I am already here. It is almost like having a guard dog on your accounts." Thus, the ease of the process gave Franklin Enterprises a competitive advantage. For example, Cody recalled an instance where a company in Baltimore, who had had their entire warehouse bar coded, was approached by a competitor with lower prices. The client remained a customer of Franklin Enterprise, as according to them, it was so much easier with Franklin Online. It is important to remember that Franklin's outside salespeople did constantly continue to work with their customers on prices.

\section{The Future}

In the next five years among its competitors, FOL wants to be the best in online services, driving upwards of $10 \%$ of all branch sales through the website. It also plans to make over 60,000 product items available online for direct orders to the consumer market. While it is not going to be Cody's responsibility, the decision to extend the online services to this market as well has been made. 
Exhibit 1: Competition for FOL

\begin{tabular}{|l|l|c|c|c|}
\hline \multicolumn{2}{|c|}{} & $\begin{array}{c}\text { Website Sophistication \& } \\
\text { Effectiveness }\end{array}$ & $\begin{array}{c}\text { Product Variety \& } \\
\text { Availability }\end{array}$ & Inventory Management Systems \\
\hline \multirow{2}{*}{ Direct } & National & X & X & X \\
\cline { 2 - 5 } & Regional & Forestville \& Direct Supply & Forestville, Direct Supply & Essential Wholesalers \& Buckley Supply \\
\hline \multirow{2}{*}{ Indirect } & National & Gavin & Gavin & X \\
\cline { 2 - 5 } & Regional & $X$ & $X$ & $X$ \\
\hline
\end{tabular}

Source: Derived by authors from interview data

Exhibit 2: Organizational Chart $\sim$ eBusiness

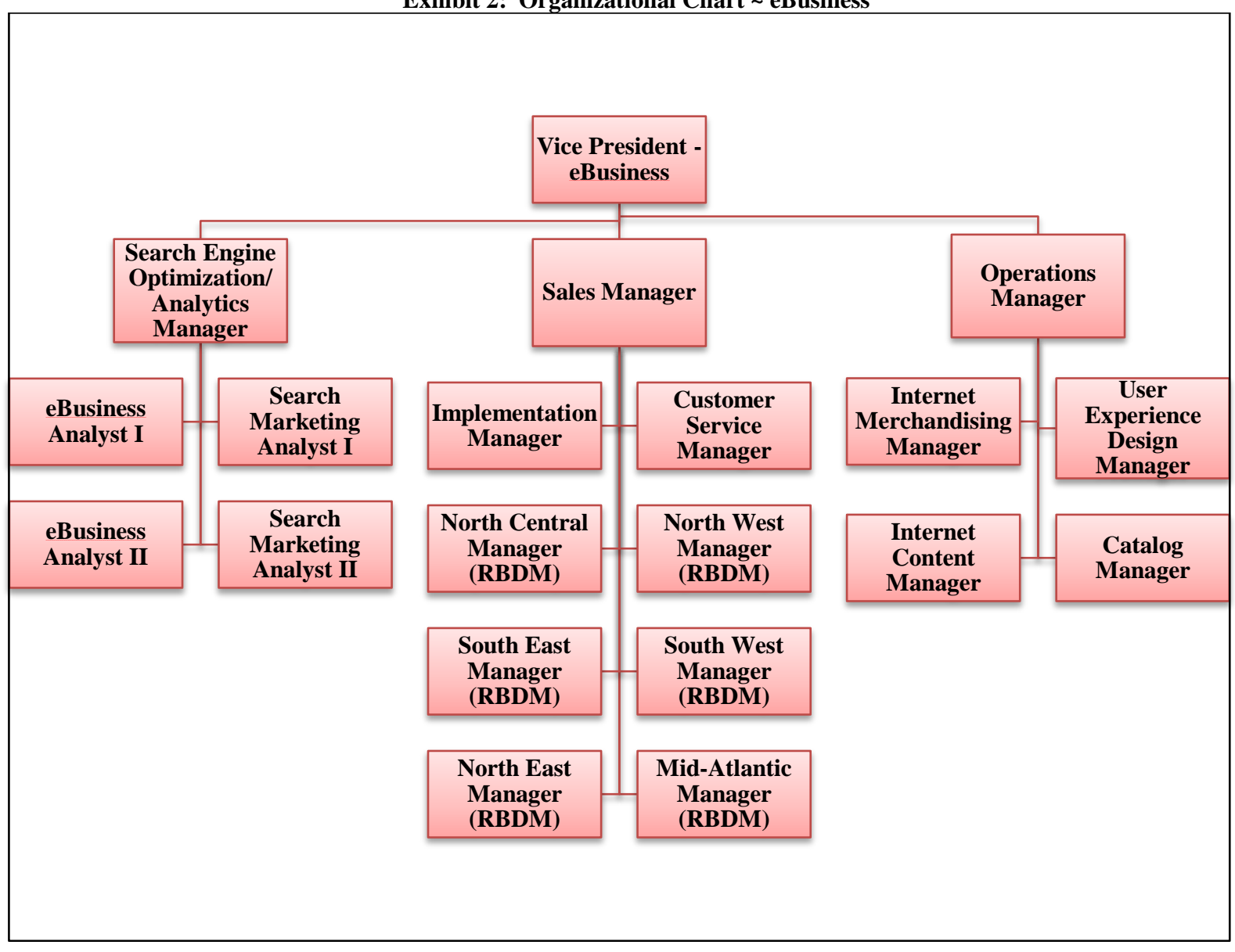


Exhibit 3: Organizational Chart North East Division

\begin{tabular}{|c|c|c|c|c|}
\hline & & $\begin{array}{r}\text { Cod } \\
\text { North E } \\
\text { ( } \\
\end{array}$ & \begin{tabular}{l|} 
ewis \\
Manager \\
M)
\end{tabular} & \\
\hline $\begin{array}{l}\text { Wat } \\
\text { Prof }\end{array}$ & $\begin{array}{l}\text { Vorks } \\
\text { nters }\end{array}$ & Plum & $\begin{array}{l}\text { Profit } \\
\text { ers }\end{array}$ & $\begin{array}{c}\text { HVAC Profit } \\
\text { Centers Sales } \\
\text { Person }\end{array}$ \\
\hline $\begin{array}{l}\text { Mid Atlantic } \\
\text { Territory Sales } \\
\text { Person }\end{array}$ & $\begin{array}{c}\text { Delaware Valley } \\
\text { Territory Sales } \\
\text { Person }\end{array}$ & $\begin{array}{c}\text { Rochester } \\
\text { Territory Sales } \\
\text { Person }\end{array}$ & $\begin{array}{c}\text { Boston Territory } \\
\text { Sales Person }\end{array}$ & \\
\hline $\begin{array}{l}\text { Vermont } \\
\text { Territory Sales } \\
\text { Person }\end{array}$ & & $\begin{array}{c}\text { New Jersey } \\
\text { Territory Sales } \\
\text { Person }\end{array}$ & $\begin{array}{c}\text { Philadelphia } \\
\text { Territory Sales } \\
\text { Person }\end{array}$ & \\
\hline & & $\begin{array}{c}\text { Pittsburgh } \\
\text { Territory Sales } \\
\text { Person }\end{array}$ & & \\
\hline
\end{tabular}

Exhibit 4: Organizational Chart $\sim$ Branch Offices

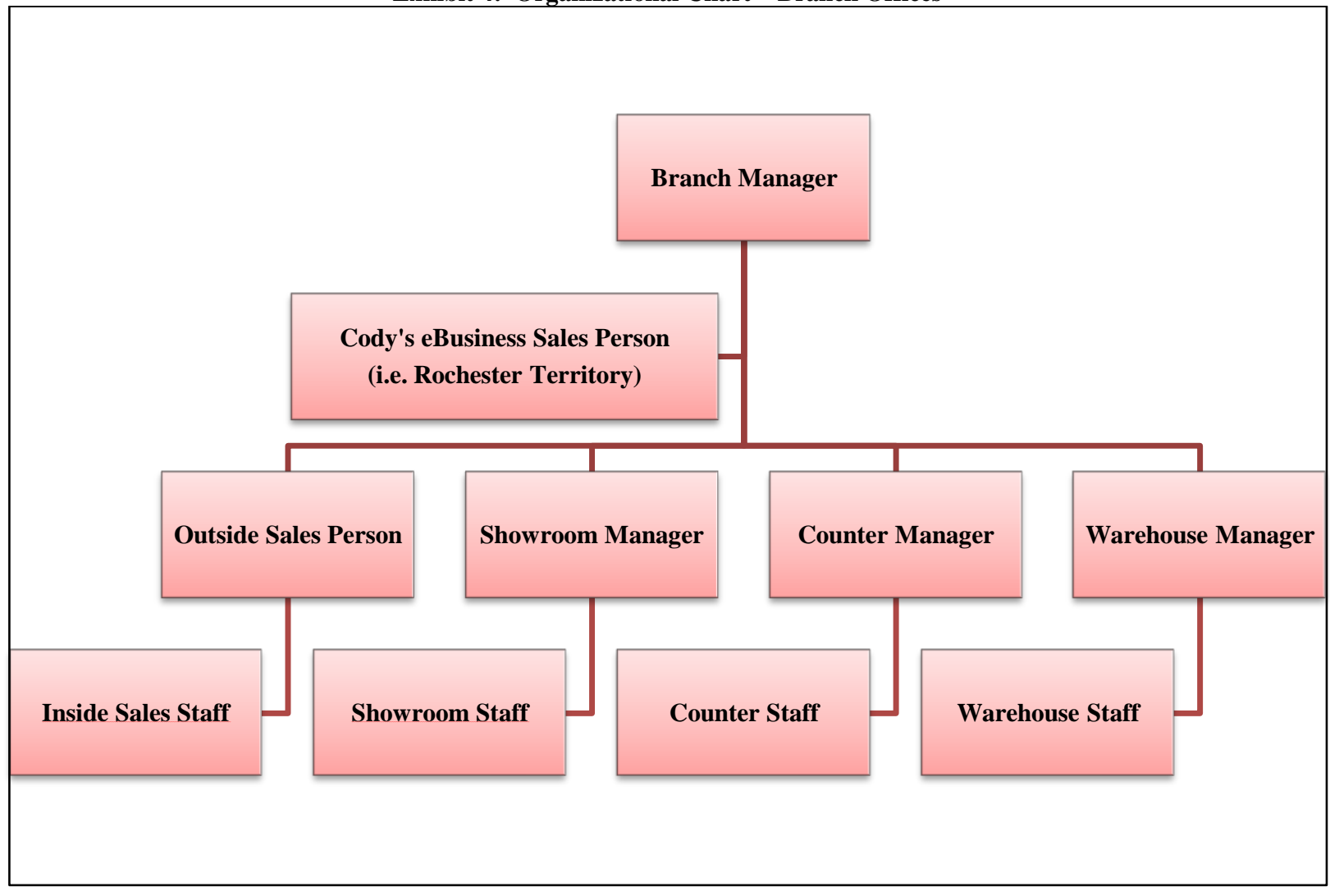




\section{AUTHOR INFORMATION}

Crystal L. Ellis is a Ph.D. student in the Earl G. Graves School of Business and Management, Morgan State University. Her Masters in Business Administration and Bachelors of Science degrees are in the College of Business from Frostburg State University. She has presented at conferences such as the SEInforms and the Eastern Academy of Management. E-mail: crell1@morgan.edu

Nathan K. Austin is an Associate Professor in the Earl G. Graves School of Business and Management, Morgan State University. He teaches professional seminar at the doctoral level and some undergraduate courses in marketing and hospitality management. He has published in refereed journals such as the International Journal of Tourism Research, Journal of Business Management and Change, World Journal of Tourism Small Business Management, Journal of Internet Commerce, International Journal of Logistics: Research and Applications and the Journal of African Business. E-mail: nathan.austin@morgan.edu

\section{REFERENCES}

1. Hill, C.W.L., \& Jones, G.R. (2008). Strategic Management An Integrated Approach. Boston, MS: Houghton Mifflin Company.

2. Oswald, S.L., Mossholder, K.W. \& Harris, S.G. (1997). Relations between strategic involvement and managers' perceptions of environment and competitive strengths: The effect of vision salience, Group \& Organization Management, 22(3): 343-365.

3. Rinke, W.J. (1989). Empowering your team members, Supervisory Management, 34(4): 21-25.

4. Thompson Jr., A.A., \& Strickland III, A.J. (1990). Strategic Management Concepts and Cases. Boston, MS: McGraw-Hill Companies.

5. Tregoe, B.B. \& Tobia, P.M. (1989). Getting everyone to think strategically, Chief Executive, 53: 62-66. 
Journal of Business Case Studies - November/December 2011 Volume 7, Number 6 NOTES 